\title{
TITLE:
}

\section{CONTRIBUTIONS TO JAPANESE ASCIDIAN FAUNA -VIII. SPORADIC MEMORANDUM(1)-}

$\operatorname{AUTHOR}(\mathrm{S})$ :

Tokioka, Takasi

\section{CITATION:}

Tokioka, Takasi. CONTRIBUTIONS TO JAPANESE ASCIDIAN FAUNA -VIII. SPORADIC MEMORANDUM(1)-. PUBLICATIONS OF THE SETO MARINE BIOLOGICAL LABORATORY 1954, 4(1): $67-68$

ISSUE DATE:

1954-11-20

URL:

http://hdl.handle.net/2433/174500

RIGHT: 


\title{
CONTRIBUTIONS TO JAPANESE ASCIDIAN FAUNA \\ VIII. SPORADIC MEMORANDUM (1) ${ }^{1)}$
}

\author{
TAKASI TOKIOKA
}

Seto Marine Biological Laboratory, Sirahama

With Plate III

Synoicum jordani (RITTER), 1899

\begin{abstract}
Aplidiopsis jordani-RitTer, W.E. (1899): A contribution to the knowledge of the tunicates of the Pribilof Islands, Fur seals and fur-seal islands of the North Pacific Ocean, Pt. 3, p. 521, Figs. 19 and 20.
\end{abstract}

Macroclinum jordani-HARTMEYer, R. (1903): Fauna Arctica, Bd. III, pp. 322-324.

Synoicum jordani-VAN NAME, W.G. (1945): Bull. American Mus. Nat. Hist., Vol. 84, pp. 64-65.

A large nearly spherical colony was trawled by the Syunkotu Maru, a surveying ship of the Bureau of the Marine Investigations from the depths of Okhotsk Sea, shallower than $200 \mathrm{~m}$, off the west coast of Kamtchatka, $54^{\circ} 07^{\prime} \mathrm{N} \times 155^{\circ} 09^{\prime} \mathrm{E}$, on Sept. 1, 1937. The colony attached to the $75 \mathrm{~mm}$ long gastropod shell harbouring a large hermit crab is $125 \mathrm{~mm}$ in length, $115 \mathrm{~mm}$ in width, $75 \mathrm{~mm}$ in thickness and $870 \mathrm{gr}$. in weight.

It is pale purplish pink in colour and sprinkled with pinkish zooids. The surface is smooth and nearly free from foreign matters except for a small amount of sand grains and hydrozoan colonies on the basal portion which is somewhat harder than the other part of the colony. A few deep grooves divide the surface of the colony into several irregular areas. Test gelatinous, though rather hard. Zooids arranged in abundant systems consisting each of 7-10 zooids surrounding a common cloacal aperture and usually $5-7 \mathrm{~mm}$ in diameter.

Zooid: The largest zooid examined is $31 \mathrm{~mm}$ in length. Thorax strongly contracted in all examined zooids and flesh in colour. Abdomen about twice as long as contracted thorax. Postabdomen very long, may reach ca. 5 times as long as abdomen. No constriction between the thorax and the abdomen nor between the abdomen and the postabdomen.

1) Contributions from the Seto Marine Biological Laboratory, No. 239.

Publ. Seto Mar. Biol. Lab., IV (1), 1954. (Article 7) 
Thorax: Branchial aperture 6-lobed, atrial languet present, but very short in the contracted state. Rows of stigmata ca. 15 ; probably more than 15 ?

Abdomen: Stomach situated near the middle of the abdomen; globular in outline, smoothly surfaced and constricted very distinctly from both oesophagus and hind stomach. Middle intestinal portion very distinct, constricted clearly from other parts of the alimentary canal and passes to the rectum at the posterior end of the intestinal loop. The proximal part of the rectum is constricted distinctly but forms no coecum.

Postabdomen: About a dozen yellowish brown ova just behind the intestinal loop. A compact tissue nearly as long as the ovary and following it is considered to be the testis. Postabdomen is narrowed and becomes colourless for a short distance behind the testis, then thickened again posteriorly; this part is somewhat pinkish in colour and packed compactly with corpuscular cells.

Larva: A larva found in a zooid is about $1.1 \mathrm{~mm}$ in length of the trunk, the anterior part of which is somewhat narrowed. Attachment processes 2? Larval test sprinkled with many small patches of minute granules in the anterior half.

Remarks: A considerable number of species of Synoicum are reported by REDIKORzeY from Okhotsk Sea and the Sea of Japan. Of those, S. jacobsoni RED. and S. derjugini RED. resemble the present specimen most closely in the shape and appearance of the colony. However, both species differ distinctly from the present species in the appearance of the stomach which is provided with tubercular processes on the surface in the former. The specimen is deposited in the Biological Laboratory in the Imperial Palace, Sp. No. 120.

\section{Distribution: Bering Sea and Bering Strait.}

\section{EXPLANATION OF PLATE III}

Fig. A. Synoicum jordani (RITTER), total colony.

Fig. B. Four systems.

Fig. C. Zooid.

Fig. D. Larva. $(\times 75)$ 
Publ. Seto Mar. Biol. Lab., IV, 1 (1954) PLATE III

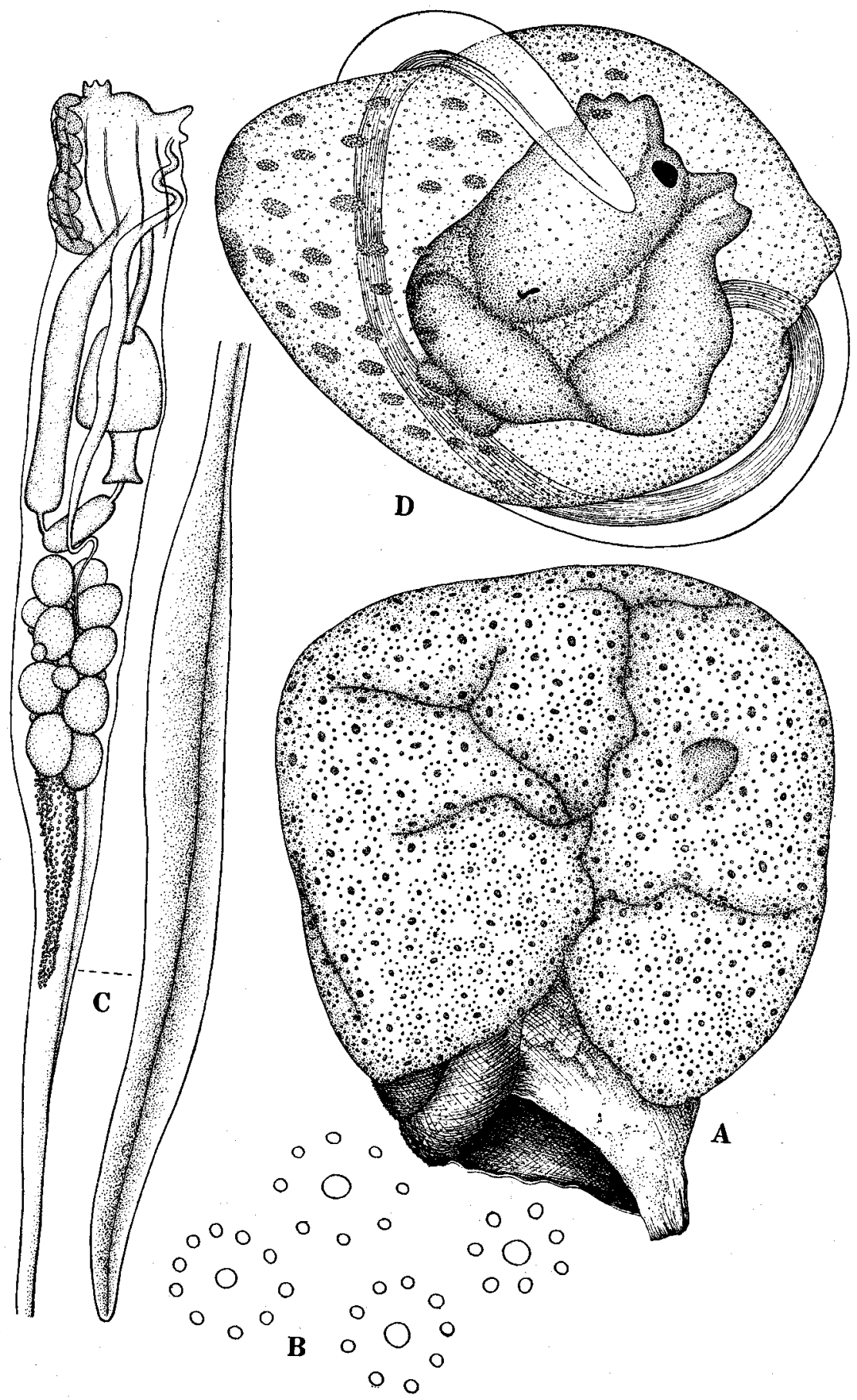

T. Tokioka: Contributions to Japanese Ascidian Fauna, ViII. 